\title{
PENGARUH PENGGUNAAN JENIS BAHAN PENGGUMPAL LATEKS TERHADAP MUTU SIR 20
}

\section{EFFECT OF THE LATEX COAGULANT USED TO QUALITY OF SIR 20}

\author{
Ganif Hidayoko $^{2}$, Okta Wulandra ${ }^{1}$ \\ ${ }^{1}$ Program Studi Teknologi Pertanian Fakultas Pertanian UNIVED Bengkulu \\ ${ }^{2}$ Program Studi Teknologi Pangan Fakultas Pertanian UNIVED Bengkulu
}

\begin{abstract}
ABSTRAK
Indonesia merupakan Negara produsen karet alam nomor dua terbesar di dunia setelah Thailand. Kelemahan utama karet alam bila dibandingkan dengan karet sintetik terletak pada konsistensi mutunya. Telah dilakukan penelitian yang bertujuan untuk mengetahui pengaruh bahan penggumpal tawas, asam asetat dan TSP (Triple Super Phosphat) terhadap kadar abu dan nilai Plasticity Retention Index (PRI) karet (Standard Indonesian Rubber) SIR 20 yang dihasilkan. Penelitian dilakukan 2 (dua) tahap, yaitu tahap pengolahan karet SIR 20 dengan bahan dasar lateks. Penggumpalan lateks dilakukan dengan variasi perlakuan bahan penggumpal, yakni tawas, asam asetat dan TSP. Setelah terbentuk karet SIR 20, selanjutnya dilakukan analisis kadar abu dan analisis nilai PRI. Rancangan percobaan yang digunakan adalah Rancangan Percobaan Faktorial dengan faktor tunggal, yaitu jenis bahan penggumpal yang terdiri dari larutan TSP $20 \%$, larutan tawas $20 \%$ dan larutan asam asetat $20 \%$ dengan tiga kali pengulangan perlakuan, jika terdapat perbedaan yang nyata, maka dilakukan uji lanjutan dengan uji DMRT. Hasil penelitian menunjukkan bahwa penggunaan bahan penggumpal asam asetat dan tawas menghasilkan karet SIR 20 dengan kadar abu dan nilai PRI yang telah memenuhi standar yang ditetapkan oleh SNI 06-1903-2000, sedangkan bahan penggumpal TSP menghasilkan karet SIR 20 dengan nilai PRI yang telah sesuai dengan standar, akan tetapi kadar abu di atas standar yang ditetapkan oleh SNI.
\end{abstract}

Kata kunci : lateks, bahan penggumpal, SIR 20

\section{ABSTRACT}

Indonesia is the number two country 's that produce of natural rubber in the world after Thailand. The main drawback of natural rubber when compared to synthetic rubber is in the consistency of its quality. The aim of this research is to determine the effect of coagulant agent : alum, acetic acid and TSP ( Triple Super Phosphate) on the ash content and the value of plasticity retention index ( PRI) of SIR 20 ( Standard Indonesian Rubber). Research conducted two (2) stages, namely the stage of processing rubber SIR 20 with latex base material. Clots made with latex coagulant treatment variations, which alum, acetic acid and TSP. Once formed rubber SIR 20, then analyzed ash content and value analysis PRI. The experimental design used was a factorial design experiment with a single factor, namely the type of coagulant consisting of a $20 \%$ solution of TSP, $20 \%$ alum solution and $20 \%$ acetic acid solution with three times repetition of treatment, if there is a real difference, then tested further by DMRT. The results 
showed that the use of acetic acid coagulant and alum produce rubber SIR 20 with ash content and PRI value that meets the standards set by SNI 06-1903-2000, whereas coagulant TSP produce rubber SIR 20 with PRI values that are in accordance with standard, but the ash content above the standards set by the SNI.

Keywords : latex, coagulant, SIR 20

\section{PENDAHULUAN}

Indonesia merupakan negara produsen karet alam nomor dua terbesar di dunia setelah Thailand. Menurut data dari Dirjenbun tahun 2005, total luas area perkebunan karet di Indonesia mencapai 3,29 juta ha, yang 85,3 $\%$ (2,829 juta ha) merupakan perkebunan karet rakyat. Adapun 14,7 \% (0,461 juta ha) adalah perkebunan besar swasta dan perkebunan besar negara (Ditjenbun, 2005). Permintaan karet alam dunia semakin menjanjikan dengan dikembangkannya bermacam-macam kendaraan dengan banban mati hasil penemuan Goodyear pada tahun 1837, disusul dengan penemuan dari Dunlop pada tahun 1888 yang berhasil membuat ban angin, dan semakin diperkuat dengan pengembangan pembuatan ban-ban angin untuk mobil yang dilakukan Michelin di Perancis. Dalam industri ban otomotif, komponen karet yang diperlukan terdiri dari $74 \%$ karet sintetis dan $26 \%$ karet alam. Khusus dalam industri ban radial untuk mobil penumpang dan truk, penggunaan karet alam mencapai $65 \%$ dari total konsumsi karet alam. Komponen karet alam diperlukan untuk memberikan beberapa sifat unggul dari ban seperti kekuatan ban mentah (green strength), kalor timbul (heat build up) yang rendah dan tekanan gelinding (rolling resistance) yang kecil.

Kelemahan karet alam yang utama bila dibandingkan dengan karet sintetis terletak pada konsistensi mutunya. Kendala utama yang dihadapi untuk meningkatkan konsistensi mutu karet alam adalah variasi jenis dan mutu bahan olah yang ada, khususnya bahan olah karet rakyat (BOKAR), terutama setelah dilakukan pengembangan tanaman karet secara besarbesaran melalui pola PIR (Perkebunan Inti Rakyat) pada awal tahun 1980-an. Bokar merupakan bahan olah industri karet remah (Crumb Rubber) yang berasal dari lateks yang menggumpal atau digumpalkan sebelum dijual ke pemasok atau dikirim ke pabrik.

Berdasarkan survei yang telah dilakukan oleh penulis, diperoleh fakta bahwa petani 
peserta Perkebunan Inti Rakyat (PIR) beranggapan bahwa norma pembelian bokar oleh pemasok yang berbentuk slab/lump adalah berdasarkan berat yang diserahkan sehingga ada kecenderungan perilaku petani seperti : berusaha memasukkan bahan non karet ke dalam produknya dan/atau menggunakan jenis bahan penggumpal yang tidak lazim untuk menggumpalkan produk lateks.

Beberapa bahan penggumpal lateks yang sering digunakan oleh petani adalah asam asetat, tawas dan TSP (Triple Super Posfat). Ketiga jenis penggumpal yang digunakan oleh petani tersebut diduga bisa menimbulkan adanya kotoran dalam produk lateks, sehingga mempengaruhi mutu pengolahan karet remah SIR 20 (Anonim, 2008). Berdasarkan kenyataan di atas, penulis tertarik untuk melakukan penelitian terhadap pengaruh penggunaan bahan penggumpal lateks terhadap mutu SIR 20 yang dihasilkan.

\section{Lateks}

Sebagai sumber karet alam, jenis pohon karet (Hevea brasiliensis) adalah salah satu jenis pohon yang mempunyai nilai ekonomis yang tinggi dan telah lama dikembangkan di Indonesia. Pohon karet termasuk tanaman keras yang agak besar, bisa mencapai ketinggian $\quad 10-20$ meter, memiliki percabangan yang banyak dan dari kulitnya keluar gatah, daunnya berselang-seling seperti daun ketela pohon dan berbentuk bulat elips. Tanaman karet dikategorikan matang sadap apabila ukuran lilit batang telah mencapai lebih dari $45 \mathrm{~cm}$, diukur 1 meter di atas pertautan okulasi, dan ketebalan kulit sudah mencapai $>60 \%$.

Penyadapan adalah proses pengikisan lapisan kulit pada alur sadap dengan tujuan untuk mengalirkan lateks dari pembuluh lateks. Pengikisan dilakukan dengan alat khusus yaitu pisau sadap yang mengakibatkan terjadinya pelukaan mekanis sehingga pembuluh lateks menjadi terbuka dan melepas tekanan yang diikuti mengalirnya lateks. Lateks berwarna putih yang menyerupai susu dan mengandung butir-butir karet yang merupakan larutan koloid (Anonim, 1998).

Menurut Southorn (1969) dalam Anonim (1998), lateks yang terkandung dalam pembuluh lateks mempunyai tekanan tinggi yang jika diukur dengan alat tekanan turgor tercatat di atas 10 atmosfir. Bila pohon disadap, maka saluran lateks terbuka dan lateks didorong oleh perbedaan tekanan sel, ditambah dengan tekanan permukaan lateks itu sendiri yang mengakibatkan lateks mengalir keluar. Aliran lateks akan berhenti 
setelah tekanan sel menurun. Pada dasarnya lateks yang keluar dari pohon adalah bahan olah yang bersih, tetapi akibat penanganan yang kurang seksama maka dijumpai berbagai jenis bahan olah yang mutunya sangat bervariasi sehingga untuk menghasilkan produk yang bermutu baik dengan konsistensi tinggi diperlukan perlakuan tambahan yang memerlukan biaya yang relatif besar.

\section{Standars Indonesian Rubber (SIR)}

Standars Indonesian Rubber (SIR) adalah karet alam yang diperoleh dengan pengolahan bahan olah karet yang berasal dari getah pohon karet (Havea brasiliensis) secara mekanis dengan penggumpalan secara alamiah atau menggunakan bahan kimia dengan mutu akhir yang ditentukan berdasatkan spesifikasi teknis (Setyamidjaya, 1993). Pada proses pengolahan lateks menjadi SIR, bahan baku lateks dari kebun ditimbang kemudian dimasukkan ke dalam bak penggumpalan. Bahan penggumpal dimasukkan ke dalam bak penggumpalan sambil diaduk hingga merata. Setelah lateks menggumpal dengan sempurna, tahap selanjutnya adalah pemotongan untuk mempermudah proses penggilingan. Lateks yang telah menggumpal sempurna disebut dengan slab.
Slab kemudian digiling sampai menjadi lembaran (crepe) dengan tujuan untuk mengeluarkan sebagian besar kandungan air dan menyeragamkan mutu. Crepe kemudian ditiriskan pada tahap predrying selama 1014 hari untuk penuntasan uap air yang ada di dalam crepe dengan system gantung dengan tujuan untuk menghindari terbentuknya bintik-bintik putih (white spot). Lembaran crepe diremahkan dengan scheredder kemudian disusun di dalam troli. Kepadatan remahan di dalam troli harus dijaga sedemikian rupa sehingga sirkulasi udara panas di antara celah-celah remahan dapat mengalir sempurna pada saat proses pengeringan.

Karet remah (crumb rubber) dengan kadar air $15-20 \%$ di dalam troli dimasukkan ke dalam alat pengering teknis (drier). Drier dilengkapi dengan burner sebagai tempat pemanasan udara dan blower untuk menghembuskan udara panas ke troli yang telah berisi karet remah. Sirkulasi udara panas pada karet remah berlangsung selama proses pengeringan sehingga air akan menguap dari karet remah. Pengaturan suhu udara panas selama proses pengeringan sangat penting dikontrol untuk menghasilkan mutu SIR yang baik.

Beberapa pengaruh buruk terhadap mutu SIR akibat proses pengeringan yang kurang 
baik antara lain adanya virgin rubber, yaitu terdapatnya bagian-bagian yang kurang kering (tidak masak) sehingga menjadi bagian yang mudah ditumbuhi jamur dan mengakibatkan kadar nitrogen di dalam SIR menjadi tinggi. Suhu pengeringan pada proses pengolahan SIR umumnya berkisar antara $100-120^{\circ} \mathrm{C}$.

Pengemasan karet remah SIR dilakukan dengan sistem pallet dengan menggunakan kayu sebagai rangka pallet. Karet remah kering terlebih dahulu didinginkan hingga suhu kamar kemudian ditimbang sebanyak 33,33 kg dan dipress hingga terbentuk bale berukuran 570 x $380 \mathrm{~mm}$. setiap bandela dibungkus dengan plastik polietilen dengan ketebalan 0,05 $\mathrm{mm}$ dan titik leleh maksimum $108^{\circ} \mathrm{C}$ dan berwarna transparan. Setiap pallet diisi 30 bandela dan pembungkus bandela di dalam palet digunakan plastic polietilen dengan ketebalan $0,10-0,15 \mathrm{~mm}$. pada setiap bandela dibuat pita yang terbuat dari plastic bertuliskan jenis SIR yang dihasilkan dan pada setiap palet dimuat informasi jenis mutu SIR, kode perusahaan penghasil serta kode perdagangan dan negara tujuan.

Tabel 1. Standard Indonesian Rubber (SIR) Berdasarkan SNI 06-1903-2000

\begin{tabular}{lcccccc}
\hline \multicolumn{1}{c}{ Spesifikasi } & SIR & SIR 3 & SIR 3 & SIR 5 & SIR & SIR \\
& 3 CV & L & WF & & 10 & 20 \\
\hline Kadar kotoran, \% maks (b/b) & 0,03 & 0,03 & 0,03 & 0,05 & 0,10 & 0,20 \\
Kadar abu, \% maks (b/b & 0,50 & 0,50 & 0,50 & 0,50 & 0,75 & 1,00 \\
Kadar zat menguap, \% maks (b/b) & 0,80 & 0,80 & 0,80 & 0,80 & 0,80 & 0,80 \\
PRI, min & 60 & 75 & 75 & 78 & 60 & 50 \\
PO, min & - & 30 & 30 & 30 & 30 & 30 \\
Nitrogen, \% maks (b/b) & 0,60 & 0,60 & 0,60 & 0,60 & 0,60 & 0,60 \\
\hline
\end{tabular}

Sumber : SNI 06-1903-2000

\section{TSP (Tripel Super Posfat)}

Tripel super posfat dengan rumus kimia $\mathrm{Ca}\left(\mathrm{H}_{2} \mathrm{PO}_{4}\right)$ merupakan salah satu jenis pupuk yang mengandung fosfor $(\mathrm{P})$ dalam bentuk oksida $\left(\mathrm{P}_{2} \mathrm{O}_{5}\right)$ sebesar $45 \%$. Pupuk TSP berwarna abu-abu atau coklat muda dan sebagian $\mathrm{P}$ bisa larut dalam air dan sedikit asam. (Anonim, 2002).

\section{Asam semut (asam asetat)}

Asam asetat dengan rumus kimia $\mathrm{CH}_{3} \mathrm{COOH}$ adalah salah satu asam kuat berbentuk cair yang banyak digunakan 
dalam industri pengolahan karet sebagai penggumpal lateks. Asam asetat merupakan asam karboksilat yang paling sederhana dan secara alami terdapat pada sengat lebah dan semut, oleh karena itu, secara awam asam asetat sering disebut sebagai asam semut (Anonim, 2002).

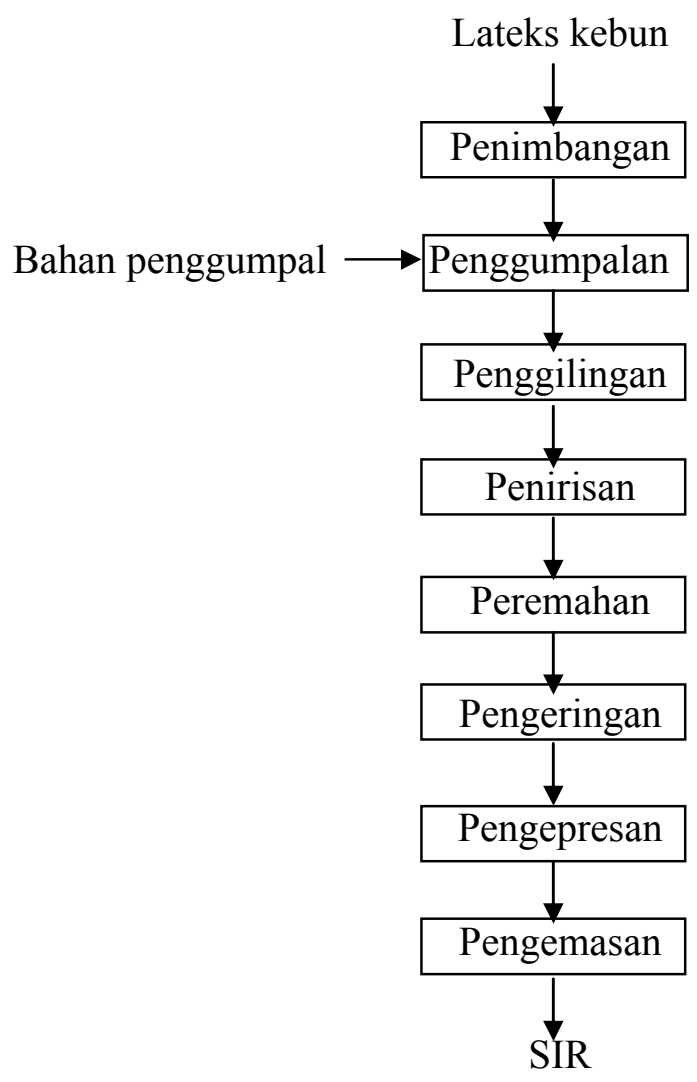

Diagram Alir Proses Pengolahan SIR

\section{Tawas}

Tawas yang mempunyai rumus kimia $\mathrm{Al}_{2} \mathrm{SO}_{4}$ banyak digunakan dalam proses penjernihan air. Secara fisik, tawas mempunyai warna putih dan larut dalam air. Tawas bisa digunakan sebagai bahan penggumpal lateks karena protein dalam lateks akan diikat oleh partikel $\mathrm{SO}_{4}{ }^{=}$yang bersifat asam (Anonim, 2002).

\section{Penentuan mutu karet remah}

Menurut Assauri (1978), istilah mutu dapat diartikan sebagai faktor-faktor yang terdapat dalam suatu barang yang menyebabkan 
barang tersebut sesuai dengan tujuan untuk apa barang tersebut dibutuhkan. Mutu suatu komoditi dapat didefinisikan sebagai gabungan sifat-sifat khas yang dapat menyebabkan masing-masing satuan dari komoditi dan memberikan pengaruh nyata dalam menentukan tingkat penerimaan konsumen.

Permintaan konsumen karet alam terhadap karet spesifikasi teknis terus meningkat seiring dengan semakin meningkatnya harga minyak dunia dan derivasinya yang merupakan bahan baku karet sintetis. Konsumen lebih menyukai jenis SIR 20 dengan mutu yang seragam dan batasan spesifikasi yang sempit daripada jenis SIR yang lain. Konsumen yang umumnya adalah pabrik ban kendaraan bermotor terkadang meminta spesifikasi yang berbeda pula. Hal ini disebabkan semakin berkembangnya teknologi ban kea rah otomatisasi dan komputerisasi proses agar kualitas ban yang dihasilkan dapat dikontrol dengan baik dengan proses pengolahan yang efisien. Keadaan ini memerlukan pasokan bahan baku dengan tingkat keragaman mutu yang tinggi (Syamsu \& Suparto, 2000).

Tiap jenis kualitas karet remah mempunyai standar tertentu dengan klasifikasi kualitas yang digolongkan berdasarkan cirri-ciri teknis. Dasar dalam penentuan klasifikasi teknis tersebut adalah kadar beberapa zat dan unsur-unsur tertentu yang terdapat dalam karet yang berpengaruh terhadap sifat-sifat akhir produk yang dibuat dari karet. Unsur-unsur dalam penetapan kualitas secara teknis antara lain adalah kadar kotoran, kadar zat menguap, kadar abu dan Plasticity Retention Index (PRI), (Setyamidjaya, 1993).

\section{Kadar abu}

Abu umumnya berhubungan dengan kotoran dan seringkali berada dalam bentuk tanah, pasir atau bahan lain yang digunakan pada proses penggumpalan lateks. Kotoran ini tidak hilang pada pemanasan $550^{\circ} \mathrm{C}$. Bahanbahan tersebut apabila terdispersi ke dalam karet akan sulit untuk dihilangkan. Penentuan kadar abu dimaksudkan untuk melindungi konsumen terhadap penambahan bahan-bahan lain ke dalam karet baik sebelum diolah maupun pada waktu pengolahannya. Kadar abu sangat besar pengaruhnya terhadap ketahanan retak dan kelenturan barang-barang yang terbuat dari karet (Setyamidjaya, 1993).

Abu di dalam karet terbentuk dari proses oksidasi karbonat dan fosfat dari kalium, magnesium, kalsium, natrium dan beberapa unsur lain dalam jumlah yang berbeda-beda. Abu dapat mengandung silikat yang berasal 
dari karet atau benda asing yang jumlah kandungannya tergantung pada pengolahan bahan baku karet. Abu dalam karet memberikan gambaran mengenai jumlah bahan mineral yang dikandungnya. Beberapa bahan mineral yang meninggalkan abu dapat mengurangi sifat dinamika yang unggul seperti kalor timbul dan ketahanan retak lentur (Martosugito, 1989).

\section{Plasticity Retention Index (PRI)}

PRI adalah suatu ukuran yang dapat digunakan sebagai indikator ketahanan karet terhadap degradasi akibat oksidasi pada suhu tinggi. Nilai PRI yang tinggi menunjukkan ketahanan terhadap degradasi yang tinggi. Dengan mengetahui nilai PRI maka dapat diperkirakan mudah tidaknya karet menjadi lengket jika disimpan atau dipanaskan. Tinggi rendahnya nilai PRI sangat tergantung dari jenis bahan olah yang digunakan dan cara pengolahannya.

Nilai PRI juga dapat digunakan sebagai petunjukan terhadap sifat fisik karet antara lain : tegangan putus (tensile strength), kepegasan pantul (rebound resilience) dan kalor timbul (heat build up). Makin tinggi nilai PRI karet mentah maka makin tinggi pula tegangan putus dan kepegasan pantul, serta semakin rendah kalor timbul dari karet (Martosugito, 1989).

\section{TUJUAN PENELITIAN}

Penelitian ini bertujuan untuk mengetahui pengaruh penggunaan bahan penggumpal tawas, asam asetat dan TSP (Triple Super Phosfat) terhadap kadar abu dan nilai Plasticity Retention Index (PRI) karet SIR 20.

\section{METODE PENELITIAN}

\section{Bahan}

Bahan-bahan yang digunakan dalam penelitian ini meliputi : lateks, air, tripel super posfat (TSP), tawas dan asam asetat $\left(\mathrm{CH}_{3} \mathrm{COOH}\right)$.

\section{Alat}

Alat yang digunakan dalam penelitian ini adalah : beker glas, gelas pengaduk, gelas ukur, timbangan, mangkuk, baki, mangel, gilingan laboratorium, gunting, neraca analitik, electric Bunsen, muffle furnace, crucible silica (cawan), vacuum decicator, thermometer, thickness gauge, walace punch dan walace steam.

\section{Cara Penelitian}

Penelitian dilakukan melalui 2 (dua) tahap, yaitu tahap penyiapan bahan larutan penggumpal lateks, dilanjutkan dengan proses pengolahan lateks. Pengolahan lateks dilakukan terhadap bahan dasar lateks yang baru disadap yang diawali dengan proses 
penggumpalan lateks dengan menggunakan variasi bahan penggumpal, yaitu larutan TSP $20 \%$, larutan tawas $20 \%$ dan larutan asam asetat 20\%. Masing-masing bahan penggumpal sebanyak $10 \mathrm{cc}$ dimasukkan ke dalam 300 cc lateks. Proses selanjutnya adalah proses penipisan sampel menggunakan mangel sehingga berbentuk lembaran dengan ketebalan $2 \mathrm{~mm}$, kemudian dikeringanginkan selama 10 hari. Analisis yang dilakukan meliputi analisis kadar abu dan analisis nilai PRI (Plasticity Retention Index).

\section{Rancangan Percobaan}

Rancangan percobaan yang digunakan dalam penelitian ini adalah Rancangan Percobaan Faktorial dengan faktor tunggal, yaitu jenis bahan penggumpal yang terdiri dari larutan TSP 20\%, larutan tawas 20\% dan larutan asam asetat 20\% dengan tiga kali pengulangan perlakuan, jika terdapat perbedaan yang nyata, maka dilakukan uji lanjutan dengan uji DMRT.

\section{HASIL DAN PEMBAHASAN}

\section{Kadar Abu}

Tabel 2. Nilai Rata-rata Analisis Kadar Abu SIR 20

\begin{tabular}{lc}
\hline \multicolumn{1}{c}{ Jenis Penggumpal } & Kadar Abu (\%) \\
\hline TSP & $1.53^{\mathrm{a}}$ \\
Asam Asetat & $0.43^{\mathrm{b}}$ \\
Tawas & $0.63^{\mathrm{c}}$ \\
Syarat SNI 06-1903-2000 & Maks 1.00
\end{tabular}

Ket : angka yang diikuti oleh huruf yang berbeda menunjukkan perbedaan yang nyata pada taraf signifikansi 5\%.

Hasil analisis kadar abu terhadap karet olahan SIR 20 disajikan pada Tabel 1 menunjukkan bahwa terdapat perbedaan yang nyata pada taraf signifikansi $5 \%$. Penggunaan bahan penggumpal TSP dan asam asetat menghasilkan karet SIR 20 yang masih dalam skala yang ditetapkan oleh SNI 06-1903-2000 yaitu di bawah angka 1.00
$(0.43 \%$ dan $0.63 \%)$, namun penggunaan tawas menghasilkan karet SIR 20 di atas standar, yaitu $1.53 \%$. Hal ini disebabkan karena asam semut dan tawas merupakan senyawa yang bersifat asam. Asam asetat selain bersifat asam, juga tidak mengandung senyawa logam, sedangkan tawas merupakan senyawa yang mengandung 
partikel $\mathrm{SO}^{4=}$ yang bersifat asam, sehingga mempunyai kemampuan pengikatan protein dalam lateks yang cukup tinggi. TSP yang digunakan sebagai bahan penggumpal ternyata menghasilkan karet SIR 20 yang mengandung kadar abu tinggi, yaitu 1.53\%, hal ini disebabkan karena TSP mengandung kalsium dan posfat yang cukup tinggi, sehingga jika ditambahkan ke dalam lateks akan membentuk senyawa kompleks yang tidak larut dalam air dan membentuk endapan yang merupakan kontaminan dalam karet SIR karena tidak menguap dengan pemanasan $550^{\circ} \mathrm{C}$ (Martosugito, 1989).

Penentuan kadar abu dimaksudkan untuk melindungi konsumen terhadap penambahan bahan-bahan lain ke dalam karet baik sebelum diolah maupun pada waktu pengolahannya. Kadar abu sangat besar pengaruhnya terhadap ketahanan retak dan kelenturan barang-barang yang terbuat dari karet. Abu umumnya berhubungan dengan kotoran dan seringkali berada dalam bentuk tanah, pasir atau bahan lain yang digunakan pada proses penggumpalan lateks. Kotoran ini tidak hilang pada pemanasan $550^{\circ} \mathrm{C}$. Bahan-bahan tersebut apabila terdispersi ke dalam karet akan sulit untuk dihilangkan (Setyamidjaya, 1993).

\section{Nilai Plasticity Retention Index (PRI)}

PRI adalah suatu ukuran yang dapat digunakan sebagai indikator ketahanan karet terhadap degradasi akibat oksidasi pada suhu tinggi. Nilai PRI yang tinggi menunjukkan ketahanan terhadap degradasi yang tinggi. Dengan mengetahui nilai PRI maka dapat diperkirakan mudah tidaknya karet menjadi lengket jika disimpan atau dipanaskan. Tinggi rendahnya nilai PRI sangat tergantung dari jenis bahan olah yang digunakan dan cara pengolahannya (Martosugito, 1989).

Nilai PRI juga dapat digunakan sebagai petunjukan terhadap sifat fisik karet antara lain : tegangan putus (tensile strength), kepegasan pantul (rebound resilience) dan kalor timbul (heat build up). Makin tinggi nilai PRI karet mentah maka makin tinggi pula tegangan putus dan kepegasan pantul, serta semakin rendah kalor timbul dari karet, (Martosugito, 1989).

Nilai PRI dapat digunakan sebagai indikator ketahanan karet terhadap oksidasi pada suhu tinggi. Nilai PRI yang tinggi menunjukkan tingkat ketahanan terhadap degradasi yang tinggi. Semakin tinggi nilai PRI maka semakin tinggi pula mutu SIR 20 yang dihasilkan. Tinggi rendahnya nilai PRI sangat tergantung dari bahan baku yang digunakan. Rata-rata nilai PRI yang terdapat 
pada karet SIR 20 pada masing-masing

perlakuan ditampilkan pada Tabel 2 .

Tabel 3. Nilai Rata-rata Analisis Plasticity Retention Index (PRI)

\begin{tabular}{lc}
\hline \multicolumn{1}{c}{ Jenis Penggumpal } & Nilai PRI \\
\hline TSP & $72^{\mathrm{c}}$ \\
Asam Asetat & $83^{\mathrm{a}}$ \\
Tawas & $76^{\mathrm{b}}$ \\
Syarat SNI 06-1903-2000 & Minimal 50 \\
\hline
\end{tabular}

Ket : angka yang diikuti oleh huruf yang berbeda menunjukkan perbedaan yang nyata pada taraf signifikansi 5\%.

Tabel 2 menunjukkan bahwa nilai PRI tertinggi terdapat pada perlakuan penggunaan bahan penggumpal asam asetat, yakni sebesar $83 \%$, nilai PRI pada perlakuan penggumpal tawas sebesar $76 \%$ dan TSP menghasilkan nilai PRI terendah, yaitu 72 $\%$. Hal ini menunjukkan bahwa penggunaan asam asetat sebagai bahan penggumpal lateks akan menghasilkan karet SIR 20 dengan nilai paling tinggi, sedangkan penggunaan TSP akan menghasilkan karet SIR 20 dengan nilai PRI paling rendah, akan tetapi masih dalam batasan aman, sesuai dengan ketentuan yang ditetapkan oleh SNI 06-1903-2000.

\section{SIMPULAN}

Penggunaan bahan penggumpal asam asetat dan tawas menghasilkan karet SIR 20 dengan kadar abu yang sesuai dengan standar SNI, yaitu masing-masing 0,43\% dan $0,63 \%$, sedangkan penggunaan TSP sebagai bahan penggumpal lateks akan menghasilkan produk SIR 20 dengan kadar abu yang tinggi, di atas standar yang ditetapkan oleh SNI, yakni $1,53 \%$. Plasticity Retention Index karet SIR 20 yang menggunakan bahan penggumpal asam asetat, tawas dan TSP masing-masing 83, 76 dan 72, yang berarti telah sesuai dengan standar yang ditetapkan oleh SNI, yakni nilai PRI minimal 50.

\section{DAFTAR PUSTAKA}

Anonim, 1998, Jenis Bahan Olah Karet dan Cara Penanganannya, Pusat Penelitian Karet Sei Putih, Tanjung Morawa.

Anonim, 2002, Asam Semut, www.wikipedia.org/wiki/asam semut. Anonim, 2008, RKAP UU Pawi, PTPN VII, Bengkulu.

Assauri, 1999, Total Quality Manajement, Penerbit Kanisius, Yogyakarta.

Martosugito, 1989, Pengolahan SIR, Departemen Perdagangan Indonesia, Jakarta. 
Setyamidjaya, 1993, Karet : Budidaya dan Pengolahan, Penerbit Kanisius, Yogyakarta.

Syamsu dan Suparto,D.Y, 2000, Evaluasi Keseragaman Po, PRI dan VR SIR 20 serta Kemampuan Proses Pengolahan Beberapa Pabrik Karet Remah Swasta di Sumatera Utara, Jurnal Teknologi Industri
Pertanian. 